\title{
Substantive and procedural criminal-law protection of human rights in the law of the European Convention on Human Rights
}

\author{
Krešimir Kamber*
}

\begin{abstract}
This article seeks to examine and explain the interaction between the substantive and procedural aspects of criminal-law protection of human rights in the practical reasoning of human rights law. It takes the European Convention on Human Rights system as an archetype for this analysis. With regard to the allocation of primacy - both in terms of importance and practical implications - to the substantive or procedural examination, the article identifies three scenarios or approaches in the European Court of Human Rights' case-law concerning the complaints raised by the victims of human rights offences. Noting certain theoretical and conceptual lacunae that arise in this context, the article attempts to suggest the most appropriate solution for the assessment of the substantive and procedural aspects of criminal-law protection of human rights from the perspective of legal theory and the Court's case-law. It submits, in particular, that it is always necessary to examine both aspects - substantive and procedural - of the same right and that the procedural aspect should be given primacy both in terms of the order of examination and inferences to be drawn on the question of observance of human rights by states.
\end{abstract}

KEYWORDS: criminal-law protection of human rights, quasi-criminal jurisdiction of international human rights courts, procedural obligation, standard of proof, burden of proof, Article 3 of the European Convention on Human Rights

\section{INTRODUCTION}

There is an increasing trend of acceptance that in some instances human rights must be protected through criminal law. This trend, however, marks a gradual development. ${ }^{1}$ Even the most adamant

\footnotetext{
*Lawyer, Registry of the European Court of Human Rights; Postdoctoral Fellow, Ghent University, Faculty of Law and Criminology. Opinions expressed are personal. This article is based on a presentation given at the conference 'Positive obligations under the ECHR and the Criminal Law: towards a Coercive Human Rights Law?' (Ghent University, Faculty of Law and Criminology, 25 May 2018).

${ }^{1}$ From a historical perspective, it is noteworthy that the due process rights of the accused have also passed through a gradual process of recognition in criminal law. In traditional criminal law theory these rights were seen as an obstacle course designed to present formidable impediments to carrying the accused any further along in the process. As such, they were seen to be in opposition to an effective mechanism of crime control exercised through the application of criminal law (see further, Packer, The Limits of the Criminal Sanction (1968)). Gradually, however, criminal law theory has abandoned this dialectic of due process rights and crime control. Now the due process rights of the accused are seen as internationally recognised 'general principles of law' which are immanent to the very concept of democracy and as such deserve a special recognition and protection in criminal process (see further, Bassiouni, 'Human Rights in the Context of Criminal Justice: Identifying International Procedural Protections and Equivalent Protections in National Constitutions' (1993) 3 Duke Journal of Comparative \& International Law (235) at 235-297; Zappalà, 'The Rights of Victims v the Rights of the Accused' (2010) 8 Journal of International Criminal Justice 137-164).
} 
believers in the conceptual and operational correctness and appropriateness of human rights protection through the mechanisms of criminal law must accept that those versed in the traditional theoretical precepts of human rights law or criminal law, respectively, will have some difficulty putting the concepts of 'human rights protection' and 'the duty to put criminal law in action' in the same equation. Indeed, some have regarded the correlation between these two concepts as an expression of a paradoxical relationship. ${ }^{2}$

Legal theory has already recognised the coercive function of human rights law and sought to explain how criminal law, traditionally seen as 'odious law' endangering human rights, could become a means of protection and enforcement of human rights. Some authors have demonstrated that the discussion should no longer turn on the question whether criminal law endangers or protects human rights, but should rather be aimed at examining the manner in which criminal law endangers and protects human rights. ${ }^{3}$

This article will attempt to take that discussion forward by seeking to elucidate the manner in which the constituent elements of the concept of 'coercive human rights law' interact in making a functional whole. More specifically, it will seek to expound the interaction between the substantive and procedural aspects of criminal-law protection of human rights in the practical reasoning of human rights law.

The term 'practical reasoning of human rights law' in this context is understood, for all practical purposes, as the examination of individual complaints in the exercise of 'quasi-criminal jurisdiction' by (international) human rights courts. ${ }^{4}$ Such jurisdiction is essentially the supervisory bodies' actual capacity effectively to review national criminal justice processes and, where necessary, trigger local prosecutions. $^{5}$

It has been shown elsewhere that this quasi-criminal jurisdiction exists in the operation of the European Convention on Human Rights (hereinafter: 'the Convention'). ${ }^{6}$ This article will therefore assume that through the adjudication of the Convention rights by the European Court of Human Rights (hereinafter: 'the Court') and the activities of the Council of Europe Committee of Ministers in the execution of the Court's judgments, the Convention system of human rights protection provides for an archetype of quasi-criminal jurisdiction.

Thus, from this perspective, inquiring into the interaction between the substantive and procedural aspects of criminal-law protection of human rights in practical legal reasoning essentially means examining the manner in which this interaction is conceived in the Court's case-law. This will accordingly be the subject of the present discussion.

\footnotetext{
2 Tulkens, 'The Paradoxical Relationship between Criminal Law and Human Rights' (2011) 9 Journal of International Criminal Justice 587, 584.

${ }^{3}$ Delmas-Marty, 'Postface : d'un paradoxe l'autre' in Cartuyvels et al. (eds), Les droits de l'homme, bouclier ou épée du droit pénal ? (2007) at 614; Kamber, Prosecuting Human Rights Offences: Rethinking the Sword Function of Human Rights Law (2017) at 6-15.

${ }^{4}$ The same jurisdiction could be conceived within the framework of a national constitutional or some other human rights discourse that has appropriately domesticated the relevant principles of international human rights law.

${ }^{5}$ See further, Huneeus, 'International Criminal Law by Other Means: The Quasi-Criminal Jurisdiction of the Human Rights Courts' (2013) 107 American Journal of International Law 1-44.

${ }^{6}$ Ibid. 23-26; Kamber, supra $\mathrm{n} 3$ at 367-375.
} 
Before proceeding with this discussion, an excursus is needed into the meaning of 'substantive' and 'procedural' protection of human rights through the mechanisms of criminal law.

\section{SUBSTANTIVE AND PROCEDURAL ASPECTS OF THE CRIMINAL LAW PROTECTION OF HUMAN RIGHTS}

In its interaction with criminal law, human rights law has a dual function. First, human rights law vests any person suspected or accused of a criminal offence with legal rights shielding him or her from state repression in the investigation and prosecution of crime. The function of human rights law is thus to neutralise the application of criminal-law mechanisms against an individual. This function is conveniently denoted as the shield function of human rights law. On the other hand, in some instances human rights law mandates the state to criminalise, investigate, prosecute and, if appropriate, punish criminal attacks on human rights. The function of human rights law in this sense is offensive and leads to triggering the application of criminal-law mechanisms rather than neutralising their effects. This is a coercive or, as descriptively denoted, a sword function of human rights law. ${ }^{7}$

For the purpose of conceptual and methodological clarity, it is of paramount importance to bear in mind that in the context of the coercive function of human rights law the criminal-law mechanisms operate not (only) because they seek to uphold the relevant public-based considerations expressed through the applicable criminal law prohibition but (also) because to criminalise, investigate, prosecute and, if appropriate, punish criminal attacks on human rights is something owed to the individual holding those rights by virtue of international human rights law.

This does not mean that the operation of criminal-law mechanisms is a private facility, disconnected from the relevant public-based considerations related to the administration of criminal law. What is in issue in this context is the enforcement, through the mechanisms of criminal law, of the requisite human rights protection, which cannot otherwise be achieved but through the application of those mechanisms, namely through investigation, prosecution and punishment of those responsible for the human rights offence. In the practical reasoning of contemporary criminal justice discourse, this (coercive) human rights component of the administration of criminal law operates concurrently with the public-based component of that activity and together with the latter conforms into a functional structure. ${ }^{8}$

For the analytical purposes of the present discussion, the coercive function of human rights law can be observed as a structure operating at two levels: substantive and procedural.

The first level concerns the substantive aspect of human rights protection through the mechanisms of criminal law. It implies criminalisation of a conduct endangering human rights and/or the functioning of the operational capacities of a state to abstain from the criminal infringement of a right or, in some instances, to prevent the risk of infringement of a right from materialising. In general, the substantive level of protection opens complex questions related to, for example, the ultima ratio societas argument and the legitimacy of the coercive function of human rights law, the principle of legality, the adequacy of alternative responses to human rights offences in the context of

\footnotetext{
${ }^{7}$ See further, Cartuyvels et al. (eds), Les droits de l'homme, bouclier ou épée du droit pénal ? (2007).

${ }^{8}$ This theory is developed in detail in Kamber, supra $\mathrm{n} 3$ (summary of findings at 3-6).
} 
criminal justice, ${ }^{9}$ or the manner in which the recourse to force and coercion is managed by the state authorities.

The foundational, and more sensitive, consideration in this context is to determine which conduct endangering human rights requires protection through criminal law. In other words, it is necessary to determine what constitutes a 'human rights offence'. For the purposes of the present discussion, the following definition, developed elsewhere, ${ }^{10}$ will be adopted:

The term human rights offences '...' denotes all criminal breaches of human rights, irrespective of whether they are committed by the state or by a private party, which attain the minimum level of severity necessary to attract the specific heightened protection under international human rights law and which should therefore constitute a criminal offence under the relevant domestic criminal law.

The second level of protection is commonly conceived as being procedural. At this level, the criminal law protection functions as an obligation on the state to put the substantive criminal-law protection into concrete action through an available and effective procedure. It is thus often denoted as a procedural obligation.

In most general terms, the procedural obligation has two modalities. In the first form, the procedural obligation designates an official duty to investigate, prosecute and, if appropriate, punish human rights offences. ${ }^{11}$ In the second form, the procedural obligation operates in the wider context of the positive duties of a state to safeguard the rights of individuals under its jurisdiction. Such a duty presupposes a more general procedural requirement of the existence of an effective independent judicial system capable of establishing the facts, holding accountable those at fault and providing appropriate redress to the victim. However, this does not necessarily mean resorting to an official criminal investigation and prosecution. Rather, it requires these legal mechanisms to exist as a range of available procedural avenues while others may exist in the sphere of civil or administrative law. ${ }^{12}$

An inquiry into the distinguishing features of the two models is beyond the reach of the present article. Moreover, for the purpose of methodological clarity, further discussion will concentrate on the first form of the procedural obligation, namely the duty to investigate, prosecute and, if appropriate, punish human rights offences.

In each case, it should be noted that the procedural obligation has developed as a separate and autonomous duty of the state, with a distinct content and underlying rationale in relation to that of protection at the substantive level. ${ }^{13}$ This relates in particular to three specific aspects of its underlying rationale, which at the same time determine its distinctive content and purposes. ${ }^{14}$

\footnotetext{
${ }^{9}$ See further, Ashworth, Positive Obligations in Criminal Law (2013).

${ }^{10}$ Kamber, supra $\mathrm{n} 3$ at 19; see also Section II (3) of the Guidelines of the Committee of Ministers of the Council of Europe on eradicating impunity for serious human rights violations of 30 March 2011.

${ }^{11}$ See, for instance, Giuliani and Gaggio v Italy [GC] Application No 23458/02, Merits, 24 March 2011 para 301.

${ }^{12}$ See, for instance, Lopes de Sousa Fernandes v Portugal [GC] Application No 56080/13, Merits and Just Satisfaction, 19 December 2017 paras 214-216.

13 Šilih v Slovenia [GC] Application No 71463/01, Merits and Just Satisfaction, 9 April 2009 para 159; Armani Da

Silva $v$ the United Kingdom [GC] Application No 5878/08, Merits, 30 March 2016 para 231.

${ }^{14}$ For a more developed discussion see Kamber, supra $\mathrm{n} 3$ at 29-77.
} 
First, the procedural obligation designates a duty of the state to put in place an institutionalised mechanism for the actual implementation of the state's positive obligations to protect the rights of individuals through the mechanisms of criminal law. The procedural obligation exists whenever the framework of positive obligations requires that a human right be protected by criminal law. The purpose of such procedural obligation is to implement the substantive criminal-law protection construed through the legal concept of positive obligations. ${ }^{15}$

Second, the procedural obligation relates to the duty of provision of effective remedies for human rights offences. It designates a form of ex post human rights protection through the mechanisms of criminal law flowing from the necessity to repair the infringed right. In this context, the purpose of the procedural obligation is not to reinforce a right but to remedy the existing infringement of the right in question. ${ }^{16}$

Lastly, the procedural obligation operates as an implied instance or inherent component of rights guaranteed under international human rights law. The procedural obligation can be deduced from every substantive right which, in the given circumstances, may be subject to a criminal infringement. In this context, the procedural obligation is regarded as an aspect of the criterion 'protected by law'. It is an ex post facto guarantee that the recognition and protection of a right is taken seriously and that any instance in which such a protection is denied will be met with an adequate procedural response by the state adhering to the rule of law. ${ }^{17}$

In the practice of human rights adjudication, the complaints raised by the victims of crime - who are at the same time holders of human rights - do not necessarily fit easily into the substantive and procedural dichotomy. The victims often simply complain that their human rights have been infringed through a criminal offence and that the state bears responsibility for what has happened. When such a complaint is made, three scenarios are possible in the practical reasoning of human rights law. In order to facilitate the discussion, an example of the prohibition of ill-treatment by state agents under Article 3 of the Convention will be used as a model to demonstrate their different features and outcomes. ${ }^{18}$

The first scenario concerns a situation in which all the relevant facts for the substantive and procedural limbs of the assessment are clear. Here the court reviewing the relevant criminal justice processes from the Convention perspective, in conducting its examination of the state's compliance with its human rights obligations towards the victim of the ill-treatment, finds that the state, through the actions of its agents, infringed (or did not infringe) the substantive protection from ill-treatment under Article 3. On a separate note, the court finds that, by failing to respond appropriately to such an occurrence by investigating, prosecuting and punishing those responsible, the state breached its

\footnotetext{
${ }^{15}$ See, for instance, M.C. v Bulgaria Application No 39272/98, Merits and Just Satisfaction, 4 December 2003 paras 149-153.

${ }^{16}$ See, for instance, Gäfgen v Germany [GC] Application No 22978/05, Merits and Just Satisfaction, 1 June 2010 para 116.

${ }^{17}$ See, for instance, McCann and Others $v$ the United Kingdom [GC] Application No 18984/91, Merits and Just Satisfaction, 27 September 1995 para 161.

${ }^{18}$ This model will accordingly reflect other instances of human rights offences by state agents, such as breaches of the right to life under Article 2 of the Convention or infringements of an individual's physical and mental integrity under Article 8 of the Convention. It, however, excludes human rights offences by private parties, who can never in international human rights law be directly responsible for breaches of the substantive aspect of a right.
} 
procedural obligation arising under the same provision. There is thus a double breach of Article 3 of the Convention: substantive and procedural. ${ }^{19}$

In the second scenario, the court finds that the victim has made an arguable claim $^{20}$ of illtreatment by state agents and that the state was under a duty to investigate, prosecute and, if appropriate, punish those responsible. When the state has failed to do that, the court finds a breach of the procedural obligation under Article 3. However, given that such a state of affairs normally creates the consequence that the circumstances of the ill-treatment itself - and thus compliance with the state's substantive duties under Article 3 - remain unclear, the court finds that the victim has failed to make a case of ill-treatment by state agents and thus finds no violation of Article 3 of the Convention in its substantive aspect. ${ }^{21}$

The third scenario is factually similar to the second. However, in this case the outcome is different. The court finds that because of the state's duty to comply with its procedural obligation concerning an arguable claim of ill-treatment under Article 3, the state has created a situation in which it failed to disprove its responsibility for the ill-treatment and is thus liable for the substantive breach itself. The court therefore finds a two-fold breach of Article 3 in its substantive and procedural aspects. ${ }^{22}$

The different scenarios essentially turn on the question of the allocation of primacy, both in terms of importance and practical examination, to the substantive or procedural aspects of the protection. Moreover, in practical reasoning, this allocation of primacy is operationalised through the specific techniques and rules related to the burden of proof. However, as will be discussed further below, in this context the operation of the strict rules on the burden of proof often makes concessions for the principle of fairness in adjudication. This is particularly true for international human rights adjudication, which is traditionally not constrained by rigid rules on the standard and burden of proof.

In the second and third scenario the emphasis is on the procedural aspect, which then becomes instrumental for the determination of compliance with the requirements of the substantive aspect of the protection. Thus, in practical reasoning the considerations of the procedural aspect have primacy over otherwise conceptually preeminent substantive protection.

\footnotetext{
${ }^{19}$ See, for instance, Vasile Victor Stanciu v Romania Application No 70040/13, Merits and Just Satisfaction, 9 January 2018 paras 46 and 53.

${ }^{20}$ In the absence of an arguable claim or credible assertion of ill-treatment, a complaint related both to the substantive and procedural aspects of the protection is manifestly ill-founded (see, for instance, Igars $v$ Latvia Application No 11682/03, Decision, 5 February 2013 para 72; Gavula v Ukraine Application No 52652/07, Merits and Just Satisfaction, 16 May 2013 para 59; Kushnir v Ukraine Application No 42184/09, Merits and Just Satisfaction, 11 December 2014 paras 103-107).

${ }^{21}$ See, for instance, Ion Bălăşoiu v Romania Application No 70555/10, Merits and Just Satisfaction, 17 February 2015 paras 101-102; Etxebarria Caballero v Spain Application No 74016/12, Merits and Just Satisfaction, 7 October 2014 para 59; Mehdiyev v Azerbaijan Application No 59075/09, Merits and Just Satisfaction, 18 June 2015 para 75.

${ }^{22}$ See, for instance, Anzhelo Georgiev and Others v Bulgaria Application No 51284/09, Merits and Just Satisfaction, 30 September 2014 para 78; Mafalani v Croatia Application No 32325/13, Merits and Just Satisfaction, 9 September 2015 para 126; Seagal v Cyprus Application No 50756/13, Merits and Just Satisfaction, 26 April 2016 para 121.
} 
On the other hand, in the first above-noted scenario, the substantive and procedural aspects of the protection operate as two distinct requirements capable of leading to two separate examinations and findings. In this case, the substantive aspect preserves its actual primacy in the assessment. The assessment of the procedural aspect is present but is ancillary.

A practical consequence of the different scenarios is twofold. First, the breach of the substantive aspect of a right carries a particular stigma for the state, which bears responsibility for the breach in question. Indeed, the finding that a state has subjected an individual to torture is not of the same nature and degree as the finding that a state has failed to investigate an arguable claim of illtreatment, which may in reality never have occurred. Secondly, as seen in the Court's case-law, the just satisfaction awards for moral damage related to the substantive breach of a right are normally much higher than for the procedural breach of the same right. ${ }^{23}$

It could be accepted that each of these approaches has a certain theoretical foundation and logic and that it is underpinned by sound practical considerations. However, the different approaches on the matter of substantive-procedural relationship create different practical consequences. Moreover, in the context of the Court's reasoning, they have been perceived as a confusion and even labelled as 'schizophrenic' by an author. ${ }^{24}$ There is therefore a pressing need to bring conceptual clarity to this relationship.

\section{SOME PRELIMINARY THOUGHTS ON THE SUBSTANTIVE-PROCEDURAL RELATIONSHIP: A THEORETICAL PERSPECTIVE}

In the abstract, the relationship between the two levels of protection - substantive and procedural is one of autonomy and connectedness. The autonomy is expressed in the fact that each level of protection can operate as a separate and autonomous set of requirements. At the same time, the central legal requirement of criminalisation of a conduct endangering human rights, which conceptually concerns the substantive aspect of the protection, is capable of becoming fully operational and effective only through the relations established within the framework of the relevant procedure. There is thus a connectedness between the two levels of protection. ${ }^{25}$

The above assertion should not be particularly controversial. However, it does not resolve the difficulty over the allocation of primacy to the substantive or procedural assessment in practical legal reasoning. It also fails to explain how to deal with the effects created by the preferred allocation of primacy. Nevertheless, this assertion, although neutral from the perspective of the substantiveprocedural primacy, is helpful for setting the scene for an overview of some of the legal theories that

\footnotetext{
${ }^{23}$ Compare, for instance, Igoshin v Russia Application No 21062/07, Merits and Just Satisfaction, 21 June 2016 para 77 and Bambayev v Russia Application No 19816/09, Merits and Just Satisfaction, 7 November 2017 para 60. In the former case, concerning only the breach of the procedural limb of Article 3 related to an arguable claim of ill-treatment by state agents, the Court made an award in respect of non-pecuniary damage in the amount of 5,000 euros. In the latter case, concerning the finding of a violation of Article 3 in its substantive and procedural limb related to torture by state agents, the Court made an award in respect of non-pecuniary damage in the amount of 45,050 euros.

${ }^{24}$ Tran, "Schizophrénie' de la Cour européenne des droits de l'homme en matière d'obligations procédurales (quelques considérations en marge des arrêts Silih c. Slovénie du 9 avril 2009, et Ersoy et Aslan c. Turquie du 28 avril 2009)' (2009) 9 L'Europe des Libertés 29 at 20-22.

25 Kamber, supra n. 3 at 15.
} 
have directly or indirectly attempted to explain the operation of the two levels of protection of human rights - substantive and procedural - in practical legal reasoning.

In an illuminating account of the matter, dating from the time when the proceduralisation of human rights was still not such a topical issue as it is today, Wolfgang Strasse ${ }^{26}$ observed a tendency in international human rights adjudication for the applicants to put forward their substantive complaints and for the international adjudicatory bodies to concentrate on procedural issues. He noted that the adjudicatory bodies tended to reject the main (substantive) complaint and subject the procedural issue to a thorough analysis. For Strasser, however, this is a misconceived choice in the adjudication. He believes that when a substantive right has been violated, the procedural assessment is irrelevant. For him, the procedural guarantees appear as empty formalities with essentially no bearing on the substantive rights.

In Strasser's view, the only relevancy that the procedural obligation might have relates to the duty of the national authorities to investigate the circumstances of the case so that the mechanism of international adjudication could conduct a reasonable supervision of all the relevant aspects of the complaint brought before it. He therefore proposes that the procedural issues be examined first with a view to determining the substantive complaint. The procedural assessment thereby becomes an indissociable aspect of the substantive right and not an aim in itself. In practice, on the assumption that only a valid procedure could create a valid outcome, when finding deficiencies in the domestic proceedings and thus a violation of the procedural aspect of the right, the international court should confine itself to noting that there is no basis on which to examine the substantive aspect of the right. Otherwise, doubt would remain as to what the outcome of the case would have been had the proceedings been fair and valid. This would, according to Strasser, eventually strengthen international adjudication and enhance the principle of subsidiarity.

Other authors have raised concerns over the tendency of the Court to substitute the procedural assessment for the substantive complaints. Eva Brems ${ }^{27}$ has argued, for instance, that detaching the procedural requirement so as to replace the substantive scrutiny essentially weakens substantive human rights protection. Françoise Tulkens ${ }^{28}$ has also cautioned that the procedural assessment should not be a substitute for the Court's duty to examine the substantive aspects of the alleged human rights violations. In her view, the procedural review should relate to the substantive assessment. Thus, once a violation of the substantive aspect has been established it may be unnecessary to examine the procedural aspect also.

Edouard Dubout ${ }^{29}$ sees the procedural and substantive protections of a right as two complementary guarantees. He draws a sensible distinction between them by observing the

\footnotetext{
${ }^{26}$ Strasser, 'The relationship between substantive rights and procedural rights guaranteed by the European Convention on Human Rights' in Matscher and Petzold (eds), Protecting Human Rights: The European Dimension, Studies in honour of Gérard J. Wiarda - Protection des droits de l'homme: la dimension européenne, Mélanges en l'honneur de Gérard J. Wiarda (1990) at 595-604.

${ }^{27}$ Brems, 'Procedural protection: An examination of procedural safeguards read into substantive Convention rights' in Brems and Gerards (eds) Shaping Rights in the ECHR (2013), at 138-139.

${ }^{28}$ Tulkens, 'Le droit à la vie et le champ des obligations des états dans la jurisprudence récente de la Cour européenne des droits de l'homme' in Amselek (ed), Libertés, Justice, Tolérance: Mélanges en hommage au Doyen Gérard Cohen-Jonhathan, Volume II (2004) at 1626.

${ }^{29}$ Dubout, 'La procéduralisation des obligations relatives aux droits fondamentaux substantiels par la Cour européenne des droits de l'homme (2007) 69 Revue trimestrielle des droits de l'homme 415.
} 
substantive protection as an obligation of result and the procedural protection as an obligation of means. In practical reasoning, this distinction translates into the fact that in order to find a substantive violation of a right it is necessary to establish a causal link between the action or inaction of the state and the infringement of the right. On the other hand, a procedural violation can be found by identifying failures in the process which have led to the absence of prevention, sanctioning and effective deterrence of a human rights offence. However, in order to make such a finding it is not necessary to identify whether the state is directly responsible for the infringement of the substantive aspect of the right.

Against this background, Dubout considers that in the interplay of the substantive and procedural assessments, the substantive should normally be given primacy. The procedural assessment is thus secondary. It may be relevant only in cases where it is impossible to impute the substantive infringement of a right to the state. Otherwise, when the impugned conduct can be imputed to the state, detaching the procedural from the substantive assessment creates the risk of a superfluous finding of two violations of the same right.

In a critical approach to these theoretical positions on the question of substantive or procedural primacy, it is submitted that, in so far as the coercive function of human rights law is concerned, there is no obstacle to examining both aspects - substantive and procedural - of the same right. Conceptually, this can be explained by the different aims pursued by the two levels of protection.

In the context of the substantive analysis, the question to be answered is whether the state bears responsibility for the substantive breach of the right, while under the procedural aspect the question is whether the state failed to react properly to an arguable claim of criminal infringement of a right by identifying, prosecuting and, if appropriate, punishing those responsible. The state has a duty to give such a procedural response in order to demonstrate to the victim (and society as a whole) its adherence to the rule of law and to dispel any appearance of collusion in or tolerance of unlawful acts. ${ }^{30}$ Moreover, as already discussed above, the state has a duty to reinforce respect for the infringed right and to provide a remedy for the existing infringement of the right in question. ${ }^{31}$ For these duties to come into play, it is immaterial whether the state actually bears responsibility for the substantive breach of the right.

In practical reasoning, it is expedient to begin to examining the procedural aspect of the protection for two reasons. Firstly, an analysis of the procedural steps taken to elucidate the circumstances of the case creates a consequential benefit for the human rights supervision by assisting it in the process of establishing the facts. This is essentially an expression of the instrumental value of the procedural obligation. ${ }^{32}$ Secondly, an effective and appropriate criminal

\footnotetext{
${ }^{30}$ Mocanu and Others v Romania [GC] Application Nos 10865/09, 45886/07 and 32431/08, Merits and Just Satisfaction, 17 September 2014 para 323.

${ }^{31}$ See further above at Section 2.

${ }^{32}$ However, this function of the procedural obligation is not capable, in itself, of justifying the nature and purpose of the procedural obligation. This is primarily because observing the procedural obligation merely as an adjudicative tool would mean that a human rights guarantee exists in order to facilitate international human rights adjudication, which would turn such adjudication into an end in itself.
} 
investigation and prosecution, combined with adequate compensation, could deprive an individual of his or her victim status for the alleged breach of the substantive right. ${ }^{33}$

In any event, the identified procedural failures in the state authorities' response to an arguable breach of the substantive right cannot ultimately work for the benefit of the state. The fact that the state authorities have failed to elucidate the circumstances of the case and thus to demonstrate their adherence to the rule of law and, if appropriate, to vindicate the infringed right should lead to a negative inference as to the substantive protection itself. In other words, if a victim has made out an arguable claim of ill-treatment by state agents, the fact that the state has failed to investigate the case properly and thus to elucidate the circumstances of the case should be a strong indication that the state is responsible for the ill-treatment itself.

Otherwise, a situation could be created in which the state, as a result of its own failures or, in some instances, deliberate omissions, could avoid a more severe finding of a violation of the substantive aspect of the right. The system of human rights adjudication could therefore inadvertently create an incentive for states not to investigate the alleged breaches of the substantive rights by their agents as this would ensure that the finding of a violation of the right in question will be limited to its procedural aspect.

Moreover, it should be accepted that the decision-maker's cognitive abilities are restricted and that his or her process of understanding of a human rights offence as a historical event is compromised by various important social and legal constraints ${ }^{34}$ preventing him or her from discovering the 'truth'. This is particularly true when the decision-maker is an international judge whose knowledge of local conditions may be limited and who is normally, in terms of time and space, dissociated from the circumstances prevailing on the occurrence of the impugned situation.

A just procedure - or diligent compliance with the procedural obligation - thus becomes crucial as the just outcome in the substantive sense is guaranteed only by a just procedure. In other words, the substantive outcome is just only to the extent to which the process aimed at its elucidation is just. ${ }^{35}$ Consequently, if there are identifiable failings in the process aimed at elucidating the circumstances of the case and holding to account those responsible for the human rights offence - which leads to the finding of a breach of the procedural aspect of the right - the only safe solution is to find a substantive breach of the right itself. From this perspective, any other outcome is mere speculation.

This does not, however, mean that every procedural deficiency which may be capable of leading to a breach of the procedural obligation should lead to the conclusion that there has been a breach of the substantive aspect of the right. Only those deficiencies that marred the investigation's capacity to elucidate the circumstances of the case should lead to such a conclusion. ${ }^{36}$ In other words, the

\footnotetext{
${ }^{33}$ Nikolova and Velichkova v Bulgaria Application No 7888/03, Merits and Just Satisfaction, 20 December 2007 para 56.

${ }^{34}$ Such as admissibility of evidence and the operation of the burden of proof, as well as the relevant social perceptions and expectations from the administration of justice. See further, Jouannet, 'La preuve comme reflet des evolutions majeures de la societe internationale' in Ruiz Fabri and Sorel (eds) La preuve devant les juridictions internationales (2007) at 239-253.

${ }^{35}$ This argument is inspired by the concept of 'pure procedural justice' as identified by John Rawls and developed in its different variants (see, for instance, Ricoeur, The Just (2000)).

${ }^{36}$ The question of the extent to which a particular deficiency in the investigation should ever in itself be capable of leading to a finding of a procedural breach is beyond the reach of this article. What is important to
} 
investigation ${ }^{37}$ must be so manifestly inadequate that the central questions related to the substantive observance of the right have remained unanswered. In line with the above discussion, this would allow for a negative inference to be drawn as to the state authorities' observance of the substantive aspect of the right.

\section{CURRENT CASE-LAW OF THE COURT}

\section{A. Introductory remarks}

Following the Grand Chamber case-law in Šilih v Slovenia, ${ }^{38}$ reaffirmed in Janowiec and Others $v$ Russia, ${ }^{39}$ it has become uncontroversial and widely accepted in the Court's case-law that the procedural obligation has developed as a separate and autonomous duty, which is always examined as a distinct issue in the assessment of the Convention rights. Indeed, in the recent Grand Chamber case of Armani Da Silva $v$ the United Kingdom, ${ }^{40}$ the Court stressed that it had "consistently examined the question of procedural obligations separately from the question of compliance with the substantive obligation".

It is true that in some instances the Court has jointly examined the substantive and procedural aspects of the protection. ${ }^{41}$ However, this was mandated by the particular factual circumstances in which the substantive outcome was so closely intertwined with the procedural assessment that it was impossible to draw a clear line between them. In any event, even in such cases, the Court often finds a double breach - substantive and procedural - of the relevant Convention right. ${ }^{42}$ This therefore reaffirms, rather than refutes, the principle of separate examination of the substantive and procedural aspects of the protection.

However, the Court's case-law on the allocation of precedence to the substantive or procedural protection does not demonstrate the existence of settled law. Indeed, all of the three abovediscussed scenarios, or their variants, of the interplay between the substantive and procedural protection can be found in some recent rulings. They will be examined in the discussion that follows. ${ }^{43}$

note here is that some deficiencies, such as lack of effective victim participation in the proceedings, will not necessarily (but may) prevent the elucidation of the circumstances of the case. Whether a particular procedural deficiency created such an effect is something to be determined on the facts of each particular case.

${ }^{37}$ In this context the term 'investigation' must be understood in a broader sense designating all criminal justice procedures aimed at establishing the circumstances of the case and punishing those responsible.

${ }^{38}$ [GC] Application No 71463/01, Merits and Just Satisfaction, 9 April 2009 para 159.

39 [GC] Application No 55598/07 and 29520/09, Merits, 21 October 2013 para 132.

${ }^{40}$ [GC] Application No 5878/08, Merits, 30 March 2016 para 231; emphasis added.

${ }^{41}$ See, for instance, Anzhelo Georgiev and Others v Bulgaria Application No 51284/09, Merits and Just Satisfaction, 30 September 2014 paras 65-78; Tiziana Pennino v Italy Application No 21759/15, Merits and Just Satisfaction, 12 October 2017 paras 55-56.

${ }^{42}$ Exceptionally, the procedural considerations may be so intertwined with the substantive assessment that no separate examination of the procedural limb is needed (Abdullah Yaşa and Others $v$ Turkey Application No 44827/08, Merits and Just Satisfaction, 16 July 2013 para 52).

${ }^{43}$ The analysis is an overview of the Court's judgments on Article 3 (examined in both its substantive and procedural limbs) related to ill-treatment by state agents, adopted between 1 January 2017 and 1 September 2018. 


\section{B. The first scenario}

As already discussed, in general terms, the first scenario concerns a situation in which all the relevant considerations for an assessment under the substantive and procedural aspects of Article 3 of the Convention are known. In such a case, the Court can rule on the substantive limb of the protection without necessarily drawing inferences from the manner of the state's discharge of its procedural obligation. Thus, here the substantive protection preserves its conceptual precedence and normally has priority in the assessment. The procedural examination is also present but is ancillary.

This approach was followed in cases concerning, in particular, police ill-treatment during an arrest ${ }^{44}$ ill-treatment of a pupil by teachers at a public nursery school, ${ }^{45}$ abduction and ill-treatment by state agents, ${ }^{46}$ an applicant's ill-treatment in detention following his extradition, ${ }^{47}$ ill-treatment during police questioning, ${ }^{48}$ stripping and placing a minor with adult detainees, ${ }^{49}$ violence by a police officer related to a private dispute, ${ }^{50}$ and violence to which a detainee was subjected by the police and prisoners acting on their instructions. ${ }^{51}$

The same approach was followed in several cases against Italy, ${ }^{52}$ which are follow-up cases to that of Cestaro $v$ Italy ${ }^{53}$ concerning acts of torture committed by members of the security forces against demonstrators at the G8 summit. Moreover, in Cirino and Renne $v$ Italy, ${ }^{54}$ concerning ill-treatment in detention by prison guards, on the basis of the available material the Court found a violation of the substantive limb of Article 3. Under the procedural limb, the Court found a breach of Article 3 referring to the structural deficiency of the Italian legal system already observed in Cestaro.

In Maslova $v$ Russia ${ }^{55}$ concerning the allegations of ill-treatment in custody and the subsequent death of a person, when finding a breach of Articles 2 and 3 of the Convention in their substantive limb, the Court relied on the findings of the domestic courts as to the authorities' responsibility for the events. However, under Article 3, the Court observed that the domestic investigation had elucidated all the circumstances of the case and that those responsible had been adequately punished. There had therefore been no breach of Article 3 of the Convention. ${ }^{56}$

Similarly, in Chatzistavrou v Greece, ${ }^{57}$ concerning allegations of police ill-treatment, the Court found that the duly conducted proceedings at the domestic level allowed it to establish all the

\footnotetext{
${ }^{44}$ Dinu v Romania Application No 64356/14, Merits and Just Satisfaction, 7 February 2017.

${ }^{45}$ V.K. v Russia Application No 68059/13, Merits and Just Satisfaction, 7 March 2017.

${ }^{46}$ Orlov and Others v Russia Application No 5632/10, Merits and Just Satisfaction, 14 March 2017.

${ }^{47}$ Mukayev v Russia Application No 22495/08, Merits and Just Satisfaction, 14 March 2017.

${ }^{48}$ Shestopalov v Russia Application No 46248/07, Merits and Just Satisfaction, 28 March 2017.

${ }^{49}$ Zherdev v Ukraine Application No 34015/07, Merits and Just Satisfaction, 27 April 2017.

${ }^{50}$ Voykin and Others v Ukraine Application No 47889/08, Merits and Just Satisfaction, 27 March 2018.

${ }^{51}$ Sergey Ivanov v Russia Application No 14416/06, Merits and Just Satisfaction, 15 May 2018.

52 For instance, Blair and Others $v$ Italy Application Nos 1442/14 and 2 others, Merits and Just Satisfaction, 26 October 2017.

${ }^{53}$ Application No 6884/11, Merits and Just Satisfaction, 7 April 2015.

${ }^{54}$ Application Nos 2539/13 and 4705/13, Merits and Just Satisfaction, 26 October 2017.

${ }^{55}$ Application No 15980/12, Merits and Just Satisfaction, 14 February 2017.

${ }^{56}$ See also Ovakimyan v Russia (Application No 52796/08, Merits and Just Satisfaction, 21 February 2017) where the Court found a violation of the substantive limb of Article 3 relying on the Government's acknowledgment of the State's responsibility for torture.

${ }^{57}$ Application No 49582/14, Merits, 1 March 2018.
} 
relevant circumstances of the case and to find that the applicant's allegations could not be sustained. The Court therefore found no violation of either the substantive or procedural limbs of Article 3.

In some cases, belonging to the group of cases following the first approach, the Court examines the procedural limb of the protection first but does not necessarily draw inferences on the substantive aspect of the examination. That was, for instance, the case in Barakhoyev $v$ Russia ${ }^{58}$ where the Court found a violation of the procedural limb of Article 3 mainly on the grounds of the protracted investigation into the applicant's allegations of ill-treatment in custody. On a separate note, having regard to the parties' arguments and the medical records available in the file, the Court found a breach of the substantive limb as well.

The procedural limb was also examined first in the two most recent secret rendition cases AlNashiri v Romania ${ }^{59}$ and Abu Zubaydah v Lithuania. ${ }^{60}$ However, these are extraordinary and highly specific cases where the secrecy surrounding the events required the Court to have recourse to all available information and to use different methods - notably a comprehensive and detailed assessment of the facts - when reaching its conclusions. In sum, the Court found a breach of the procedural and substantive limbs of Article 3.

\section{The second scenario}

The second scenario or approach encompasses instances in which the Court finds a breach of the procedural obligation under Article 3 related to the state's duty effectively to investigate, prosecute and, if appropriate, punish those responsible. However, on the substantive level, considering, or indeed directly relying on, the often-resulting lack of clarity about the circumstances of the illtreatment itself, the Court finds no violation of the substantive limb of Article 3 of the Convention. Thus, contrary to the above-discussed first scenario, the substantive issues are unknown whereas the procedural failings can be ascertained from the material available to the Court.

In the second scenario the emphasis is on the procedure, which essentially, implicitly or explicitly, becomes instrumental for the finding on the substantive aspect of the protection. Normally, the examination of the procedural limb takes precedence, in terms of both importance and practical examination, over the substantive aspect of the protection. However, variants of this model can also be found in practice.

A classic example of the second approach is the case of Thuo $v$ Cyprus ${ }^{61}$ concerning ill-treatment by state agents during a deportation process. The Court first examined the procedural limb of Article 3 and found that the authorities had not made a serious attempt to find out what had happened and had reached hasty and ill-founded conclusions concerning the cause of the applicant's injuries. It therefore found a breach of the procedural limb of Article 3. The Court then went on to examine the substantive limb and found no violation of Article 3. It reasoned as follows:

Having regard to the parties' submissions and all the material in its possession, the Court considers that the evidence before it does not enable it to find beyond all reasonable

\footnotetext{
${ }^{58}$ Application No 8516/08, Merits and Just Satisfaction, 17 January 2017.

${ }^{59}$ Application No 33234/12, Merits and Just Satisfaction, 31 May 2018.

${ }^{60}$ Application No 46454/11, Merits and Just Satisfaction, 31 May 2018.

${ }^{61}$ Application No 3869/07, Merits and Just Satisfaction, 4 April 2017, para 148.
} 
doubt that the applicant was subjected to treatment contrary to Article 3, as alleged. It particularly emphasises on that point that its inability to reach a conclusion as to whether there has been treatment prohibited by Article 3 is to a considerable extent due to the domestic authorities' failure effectively to investigate the applicant's complaint.

Interestingly, in Thuo the Court did not refer to the issue of the burden of proof as it does in cases following the third approach. A conceptually similar approach as in Thuo was followed, for instance, in Andersen $v$ Greece, ${ }^{62}$ concerning ill-treatment during arrest, and Hovhannisyan $v$ Armenia, ${ }^{63}$ concerning abuse of a civil servant in the workplace by her superiors.

A variant of the approach belonging to the second scenario can be observed in Daşlık v Turkey ${ }^{64}$ In this case the Court examined the substantive aspect first and upon its own assessment of the available evidence found that it was not possible to conclude that the applicant had been subjected to police ill-treatment. However, the Court then examined the procedural limb and found a violation of Article 3 on the grounds of a failure of the authorities to elucidate the applicant's allegations.

Further examples in the same context are Tarjáni v Hungary ${ }^{65}$ and Pihoni v Albania ${ }^{66}$ in which the evidence related to the cause of the applicants' injuries was conflicting. In both cases, the Court did not consider that knowledge of the facts lied wholly, or in large part, within the exclusive knowledge of the authorities because, in Tarjáni, a forensic report suggested that the applicant's main injury predated his arrest and in Pihoni some witnesses had also observed the event. The Court thus considered that it was for the applicants to prove beyond reasonable doubt that they had been illtreated by state agents. As they had failed to discharge that burden of proof, the Court found no violation of the substantive limb of Article 3. However, in both cases the Court found a breach of the procedural limb of Article 3 related, in particular, to the domestic authorities' failure to elucidate the circumstances of the impugned events.

The issue of the distribution of the burden of proof was addressed along the same lines in Hentschel and Stark $v$ Germany, ${ }^{67}$ concerning the use of force by the police during a football match. In its examination of the substantive limb the Court noted that the alleged violence by the police had occurred while the applicants had not been in custody or otherwise under police control. In these circumstances, the Court did not consider that the burden of proof could be shifted to the respondent Government. It held that it was for the applicants to substantiate their factual arguments by providing the Court with the necessary evidence. As they had failed to do so, the Court found no breach of the substantive limb of Article 3. On the other hand, the Court found the procedural breach of Article 3, on the grounds of a lack of comprehensiveness of the investigation.

\section{The third scenario}

The third scenario or approach is similar to the above-discussed second approach as regards the placing of decisive emphasis on the procedural protection, which then becomes instrumental for the

\footnotetext{
${ }^{62}$ Application No 42660/11, Merits and Just Satisfaction, 26 April 2018.

${ }^{63}$ Application No 18419/13, Merits and Just Satisfaction, 19 July 2018.

${ }^{64}$ Application No 38305/07, Merits and Just Satisfaction, 13 June 2017.

${ }^{65}$ Application No 29609/16, Merits and Just Satisfaction, 10 October 2017.

${ }^{66}$ Application No 74389/13, Merits and Just Satisfaction, 13 February 2018.

${ }^{67}$ Application No 47274/15, Merits and Just Satisfaction, 9 November 2017.
} 
determination of compliance with the requirements of the substantive protection. However, in this scenario the Court draws different inferences from the fact that the state failed to discharge its procedural obligation adequately. The Court finds that a failure properly to investigate an arguable claim of ill-treatment under Article 3 means that the state failed to disprove its responsibility for the ill-treatment itself and is thus liable for the substantive breach as well.

A telling example in this context is that of Grigoryan and Sergeyeva $v$ Ukraine ${ }^{68}$ concerning illtreatment in police custody motivated by ethnic prejudice. The Court first examined the procedural limb noting that the authorities had failed to conduct a full-fledged investigation into the arguable claims of police ill-treatment. The Court thus found a breach of the procedural limb of Article 3 . With regard to the substantive limb, when finding a violation of the substantive limb of Article 3 , the Court reasoned as follows:

It is well established in the Court's case-law that where the events at issue lie, in large part, within the exclusive knowledge of the authorities, and there is evidence of injuries occurring during detention, the burden of proof is on the Government to provide a satisfactory and convincing explanation by producing evidence establishing facts which cast doubt on the account of events given by the victim '...'

The Court considers that in the present case the Government have not discharged this burden of proof and, accordingly, deems it sufficiently established that force not rendered strictly necessary by the applicant's own conduct was used against him '...'

A conceptually same approach was followed in a number of other cases concerning, in particular, ill-treatment during police questioning, ${ }^{69}$ ill-treatment in police custody, ${ }^{70}$ ill-treatment during an intervention for the service of a summons to report to the police station, ${ }^{71}$ ill-treatment during arrest $^{72}$ and ill-treatment by escorting officers when taking a detained applicant to court. ${ }^{73}$

An indicative case of the group of cases belonging to the third approach is Sadkov $v$ Ukraine. ${ }^{74}$ The Court first found that an investigation into the applicant's allegations of ill-treatment in police custody had not been effective and thus in breach of the procedural limb of Article 3. On the substantive limb, the Court noted that the applicant's version of the events was inconsistent and could thus not be accepted as presented. However, the Court then stressed that it was for the State to provide a plausible explanation for injuries sustained by a person under control of the police and thus, given the absence of such an explanation, found a violation of the substantive limb of Article $3 .{ }^{75}$

\footnotetext{
${ }^{68}$ Application No 63409/11, Merits and Just Satisfaction, 28 March 2017, paras 74-75; references omitted.

${ }^{69}$ Morgunov v Russia Application No 32546/08, Merits and Just Satisfaction, 11 April 2017.

${ }^{70}$ Kondakov v Russia Application No 31632/10, Merits and Just Satisfaction, 2 May 2017.

${ }^{71}$ Shevtsova v Russia Application No 36620/07, Merits and Just Satisfaction, 3 October 2017.

72 Devyatkin v Russia Application No 40384/06, Merits and Just Satisfaction, 24October 2017.

73 Ostrovenecs v Latvia Application No 36043/13, Merits and Just Satisfaction, 5 October 2017.

${ }^{74}$ Application No 21987/05, Merits and Just Satisfaction, 6 July 2017 para 101.

${ }^{75}$ See also Khani Kabbara v Cyprus Application No 24459/12, Merits and Just Satisfaction, 5 June 2018.
} 
A somewhat structurally unusual approach for the third group of cases was applied in several cases concerning complaints of police ill-treatment. ${ }^{76}$ In these cases, the procedural limb preserved its conceptual precedence but was secondary in the order of examination. The difficulty with such an approach lies in the fact that the substantive violation is found with reference to the critical procedural failures, which, however, have still not been declared contrary to the Article 3 procedural requirements.

Lastly, another variant of the approach belonging to the third scenario can be observed in Mindadze and Nemsitsveridze $v$ Georgia ${ }^{77}$ where the Court, without strictly differentiating the substantive and procedural examinations, noted a number of deficiencies in the investigation of the applicant's allegations of police ill-treatment. It thus considered that there had not been a plausible explanation for the applicant's allegations, which led to a finding of a violation of both the substantive and procedural limbs of Article 3.

\section{PUTTING THE COURT'S CASE-LAW IN A BROADER CONTEXT OF THE SUBSTANTIVE- PROCEDURAL RELATIONSHIP}

The first discussed scenario is not particularly controversial. In this scenario, the relevant circumstances of the case are known to the Court, which allows it to reach separate conclusions on the substantive and procedural aspects of the criminal-law protection.

Information on the legally relevant circumstances may be available from different sources. In some instances, it may follow from the duly conducted domestic proceedings such as in Chatzistavrou v Greece; in some instances, from the Government's or the domestic authorities' recognition of a breach of the Article 3 rights, ${ }^{78}$ and in some instances from various other sources available to the Court, as was the case in the most recent secret rendition cases of Nashiri v Romania and Abu Zubaydah $v$ Lithuania. Moreover, the Court's previous experience in dealing with a particular issue at the domestic level, such as the circumstances surrounding the police intervention into the G8 summit in Italy, ${ }^{79}$ will allow it to reach a conclusion on the substantive and procedural complaints under Article 3 in the subsequent similar cases.

In this context, however, the Court often stresses the subsidiary nature of its role and the fact that it must be cautious in taking on the role of a first-instance tribunal of fact. The Court has explained that this may be justified only when it is rendered unavoidable by the circumstances of a particular case. Otherwise, where domestic proceedings have taken place, the Court will substitute its own assessment of the facts for that of the domestic courts only exceptionally. In normal circumstances the Court requires cogent elements to lead it to depart from the findings of fact reached by those courts. ${ }^{80}$

\footnotetext{
${ }^{76}$ For instance, M.F. v Hungary Application No 45855/12, Merits and Just Satisfaction, 31 October 2017; Portu Juanenea and Sarasola Yarzabal v Spain Application No 1653/13, Merits and Just Satisfaction, 13 February 2018.

${ }^{77}$ Application No 21571/05, Merits and Just Satisfaction, 1 June 2017.

${ }^{78}$ For instance, Maslova v Russia.

79 See the follow-up case-law to the case of Cestaro $v$ Italy.

${ }^{80}$ Further, Annenkov and Others $v$ Russia (cited above) para 80.
} 
Nevertheless, according to its case-law, the Court is required to apply a 'particularly thorough scrutiny' where allegations are made under Article 3, even if certain domestic proceedings and investigations had already taken place. This means that, as the Court has explained, in examining the findings reached by the domestic authorities, it may take account of the quality of the domestic proceedings and any possible flaws in the decision-making process. ${ }^{81}$ Thus, even in the first scenario, the procedural considerations, related for instance to the thoroughness and credibility of the domestic authorities' findings, will usually play an important role in reaching a conclusion on the (non-)compliance with the substantive and procedural requirements of Article 3.

The second and the third approach discussed above are more controversial, particularly concerning the determination of the substantive aspect of the protection. In practical reasoning the difference in the approaches, and thus in the outcomes of the assessment, rests on the manner in which the rules on the burden of proof are used. In the third scenario, the burden of proof shifts to the authorities to provide a satisfactory and convincing explanation for the arguable allegations of illtreatment. Thus, failings in the proceedings set in motion to provide such an explanation lead to an adverse finding on the compliance with the substantive aspect of the protection.

On the other hand, in the second scenario, the burden of proof is not shifted to the authorities and thus the procedural failures do not lead to an adverse finding on the substantive aspect of the protection. This approach has ordinarily given rise to a discomfort on the part on some judges, who in their separate opinions have stressed that the obligation is on the respondent state to conduct an effective investigation capable of providing explanation for an arguable claim of the substantive breach of a right. According to them, a failure to do so on the part of the state authorities should lead to the drawing of negative inferences on the authorities' responsibility for the substantive breach of the right. ${ }^{82}$

The majority of recent cases follow the line of reasoning belonging to the third approach. However, the differences in the approaches demonstrate that the Court's case-law still does not seem to be settled on the matter of the allocation of the burden of proof in cases involving the substantive and procedural aspects of the criminal-law protection. Consequently, uncertainty is created in the operation of the substantive-procedural relationship in the Convention law.

An attempt will therefore be made to put these approaches into a general context of the substantive-procedural relationship and - having regard to the above outlined theoretical considerations - to suggest the most appropriate solution for the methodology to be applied in human rights adjudication when dealing with the issue of the substantive-procedural relationship.

\footnotetext{
${ }^{81}$ Bouyid v Belgium [GC] Application No 23380/09, Merits and Just Satisfaction, 28 September 2015 para 85.

${ }^{82}$ See, for instance, the dissenting opinion of judges I. Cabral Barreto, V. Zagrebelsky and D. Popović in Ersoy and Arslan v Turkey Application No 16087/03, Merits, 28 April 2009, and the partially dissenting opinion of Judge L.-A. Sicilianos in the case of Mehdiyev v Azerbaijan Application No 59075/09, Merits and Just Satisfaction, 18 June 2015.
} 
For that purpose, an excursus is warranted on the issue of the standard and burden of proof in the Court's case-law under Article 3 of the Convention, which is in practical reasoning the mechanism through which the allocation of the substantive-procedural primacy is operationalised ${ }^{83}$

The well-established principles on the standard and the burden of proof in Article 3 cases have been reiterated in the recent Grand Chamber case of Bouyid $v$ Belgium ${ }^{84}$ in the following manner:

\begin{abstract}
Allegations of ill-treatment contrary to Article 3 must be supported by appropriate evidence. To assess this evidence, the Court adopts the standard of proof 'beyond reasonable doubt' but adds that such proof may follow from the coexistence of sufficiently strong, clear and concordant inferences or of similar unrebutted presumptions of fact '...'

On this latter point the Court has explained that where the events in issue lie wholly, or in large part, within the exclusive knowledge of the authorities, as in the case of persons within their control in custody, strong presumptions of fact will arise in respect of injuries occurring during such detention. The burden of proof is then on the Government to provide a satisfactory and convincing explanation by producing evidence establishing facts which cast doubt on the account of events given by the victim '...' In the absence of such explanation, the Court can draw inferences which may be unfavourable for the Government '...'

'...' [T]he principle set forth in paragraph 83 above applies to all cases in which a person is under the control of the police or a similar authority.
\end{abstract}

It should be stressed at the outset that the Court's rules on the standard and burden of proof may simply be taken as part of its inherent right to manage its own evidence law. And in this context, there is no uniform, ${ }^{85}$ or for that matter right or wrong, setting of the standard of proof or allocation of the burden of proof by an international court or tribunal. ${ }^{86}$

Moreover, matters such as the burden of proof are dependent on the substantive issues in question. ${ }^{87}$ Indeed, the Court has explained that the level of persuasion necessary for reaching a particular conclusion and, in this connection, the distribution of the burden of proof, are intrinsically linked to the specificity of the facts, the nature of the allegation made and the Convention right at

\footnotetext{
${ }^{83}$ The issue of the standard of proof is so closely interwind with the issue of the burden of proof that it is impossible to dissociate them in the discussion. See further, Thienel, 'The Burden and Standard of Proof in the European Court of Human Rights' (2007) 50 German Yearbook of International Law 544.

${ }^{84}$ Paras 82-84; references omitted.

${ }^{85}$ See further, Shelton, 'Judicial Review of State Action by International Courts' (1998) 12 Fordham International Law Journal 3 at 361-398; Paúl, 'In Search of the Standards of Proof Applied by the Inter-American Court of Human Rights' (2012) 55 Revista IIDH 57-102.

${ }^{86}$ In fact, the rules on the standard and burden of proof have never been the central preoccupation of international judicial bodies. This is primarily borne out of the fact that international legal disputes mostly turn on the questions of law, rather than fact, and that parties have a duty to cooperate diligently on the matters related to facts with the international court or tribunal (see further, Foster, 'Burden of Proof in International Courts and Tribunals' (2010) 29 Australian Year Book of International Law at 28-29, 60). Nevertheless, issues related to the standard and burden of proof are some of the most important concerns of litigants (Alford, 'The Proliferation of International Courts and Tribunals: International Adjudication in Ascendance' (2000) 9 NDL Scholarly Works at 162). Thus, the necessity of consistency and clarity in this context is very important and needed.

87 Thienel, supra $\mathrm{n} 83$ at 550.
} 
stake' and that '[it] is also attentive to the seriousness that attaches to a ruling that a Contracting State has violated fundamental rights'.$^{88}$

The current discussion is not so concerned with the issue of the standard of proof since, as explained above, the different approaches in the operationalisation of the substantive-procedural relationship in the sphere of criminal-law protection of human rights turn on the question of the allocation of the burden of proof rather than different standards of proof.

It is, however, worth noting that the standard of proof 'beyond reasonable doubt' ${ }^{89}$ has given rise to controversy and criticism both in legal theory and in dissenting opinions of the Court's judges. One author has considered it to be 'shrouded in mystery' ${ }^{90}$ and the dissenting judges have considered it to be unexplained, ${ }^{91}$ and misconceived ${ }^{92}$ as it is the standard usually applied in criminal proceedings, which, unlike international adjudication of state responsibility, operate under the principle of the presumption of innocence.

Moreover, other authors have suggested that the most appropriate standard to adopt for general application in most situations of international adjudication would be that of the 'balance of probabilities' or 'preponderance of the evidence' ${ }^{93}$ as applied in the common law systems in civil cases, or another similar test lower than that of proof 'beyond reasonable doubt'. However, these authors accept that there may be a need for a higher standard of proof for the most serious allegations of human rights breaches. ${ }^{94}$

The Convention institutions' reference to the standard of proof 'beyond reasonable doubt' dates back to European Commission of Human Rights' case-law in The Greek Case and it was first established in the context of Article $3 .{ }^{95}$ This case-law was then reaffirmed by the Court in Ireland $v$ the United Kingdom ${ }^{96}$ and has been used ever since. ${ }^{97}$ The standard of 'beyond reasonable doubt' in this context means reaching a conclusion which is beyond a doubt that is based on a mere theoretical possibility or raised in order to avoid a disagreeable conclusion. A 'reasonable' doubt is one for which reasons can be based on the facts presented. ${ }^{98}$

\footnotetext{
${ }^{88}$ El-Masri $v$ the former Yugoslav Republic of Macedonia [GC] Application No 39630/09, Merits and Just Satisfaction, 13 December 2012 para 151.

${ }^{89}$ The standard of proof used in criminal cases in common law systems is determined as proof 'beyond reasonable doubt'. It normally denotes a situation in which the state of affairs is such that a conclusion in favour of the defendant is possible but not in the least probable (Paúl, supra $\mathrm{n} 85$ at 63).

90 Thienel, supra $\mathrm{n} 83$ at 566.

${ }^{91}$ Partly dissenting opinion of Judge Bonello (paras 9-10) in Anguelova v Bugaria Application No 38361/97, Merits and Just Satisfaction, 13 June 2002.

92 Partly dissenting opinion of Judge Loucaides in Hasan Ilhan v Turkey Application No 22494/93, Merits and Just Satisfaction, 9 November 2004.

${ }^{93}$ This is in general considered to be a situation where evidence adduced by one party is greater in weight in comparison with the evidence adduced by the other party. The assertion supported by such evidence must be convincing in the sense that it must be 'more likely than not' to be true (Thienel, supra $\mathrm{n} 83$ at 567).

${ }^{94}$ Foster, supra $\mathrm{n} 86$ at 61-62; Thienel, supra $\mathrm{n} 83$ at 581-585.

95 The Greek Case (Denmark v Greece; Norway v Greece; Sweden v Greece; the Netherlands v Greece) Application Nos. 3321/67 et al., Commission Report, 5 November 1969 para 30.

${ }^{96}$ Application No 5310/71, Merits and Just Satisfaction, 18 January 1978 para 161.

${ }^{97} \mathrm{See}$, on the issue of the standard and burden of proof in general, Merabishvili v Georgia [GC] Application No 72508/13, Merits and Just Satisfaction, 28 November 2017 paras 310-317.

${ }^{98}$ The Greek Case para 30, and, more recently, Melnitis v Latvia Application No 30779/05, Merits and Just Satisfaction, 28 February 2012 para 68.
} 
The Court has often stressed that proof 'beyond reasonable doubt' is not co-extensive with (or borrowed from) that of the national legal systems which employ it. ${ }^{99}$ However, in theory, the law of procedure is considered as one of the fields where the application of principles common to the various national legal systems is most useful. Indeed, transposition from the national to the international level of the general principles governing a procedure in the most convincing and effective manner can be contemplated in various types of international proceedings, including disputes between individuals and states. ${ }^{100}$

In this connection, drawing from the general principles of national legal orders, it should be noted that the standard of proof 'beyond reasonable doubt' is the highest standard of proof contemplated in legal procedures for reaching a particular conclusion of fact. Being normally used in criminal proceedings, this standard of proof, on the one hand, expresses various rule of law considerations in the administration of criminal law, and, on the other hand, minimises the risk of an erroneous finding of fact. ${ }^{101}$ Thus, in comparative law, this standard is sometimes used in particularly important matters belonging to civil or administrative law (where various other less rigorous standards normally apply) in order to minimise the risk of erroneous substantive outcomes. ${ }^{102}$

From this perspective, the use of a particularly high standard of proof - expressed as 'beyond reasonable doubt' - by the Court in Article 3 cases, ${ }^{103}$ seems reasonable and justified, particularly given the seriousness that attaches to a ruling that a Contracting State has violated the absolute prohibition of ill-treatment under the Convention. What is more, like the operation of the presumption of innocence in criminal law, in international law there is a generally accepted presumption of compliance by states with their international legal obligations. ${ }^{104}$ The existence of this presumption thus also justifies a high standard of proof since a finding that the state has failed to comply with its international law obligations must convincingly be established, leaving no 'reasonable' doubt to the contrary.

However, when the burden of proof is shifted to the authorities, the standard of proof of 'beyond reasonable doubt' has to be understood in the context of an individual's duty to make a prima facie case of state responsibility for his or her ill-treatment - which means making an arguable or credible claim of a breach of his or her Article 3 right - and the state authorities' duty to provide a satisfactory and convincing explanation for the particular factual allegations of ill-treatment. As borne out by the Court's case-law, in every such case, the alleged victims must provide as consistent and detailed an account as possible and all the evidence at their disposal in order to sustain their assertions, and the state must provide a satisfactory and convincing explanation by producing evidence for establishing facts which cast doubt on the account of the events given by the victim. Thus, while it may be said that, in each case, the ultimate burden to prove ill-treatment is on the victim, when the burden of

\footnotetext{
${ }^{99}$ Merabishvili v Georgia [GC] (cited above) paras 314.

100 Kinsch, 'On the Uncertainties Surrounding the Standard of Proof in Proceedings Before International Courts and Tribunals' in Venturini and Bariatti (eds) Individual Rights and International Justice (2009), at 428-429.

101 Ibid. 429-431; Paúl, supra $\mathrm{n} 85$ at 63.

102 Thienel, supra $\mathrm{n} 83$ at 568.

103 This arguably apples to all other Convention rights. See in this context Merabishvili v Georgia ([GC] paras 309-317) where the Court identified the proof of 'beyond reasonable doubt' as part of the 'usual approach' to the standard of proof in its examination of cases. However, a further discussion on the matter is beyond the reach of the present discussion.

${ }^{104}$ Foster, supra n 86 at 36-38.
} 
proof is shifted to the authorities - due to the conceptual requirements of the substantiveprocedural relationship - the standard of proof 'beyond reasonable doubt' relates to the existence of 'sufficiently strong, clear and concordant inferences or of similar unrebutted presumptions of fact', as contemplated in Bouyid, rather than to a certainty which is beyond any doubt based on a mere theoretical possibility.

As regards the bearing of the burden of proof, it is submitted that in Article 3 cases, concerning allegations of ill-treatment by state agents, where the operative (and in some instances, evidential) facts ${ }^{105}$ are unknown or unclear, it is reasonable and justified, and in fact necessary, to shift the burden of proof to the authorities to provide an explanation for the prima facie credible allegations of state responsibility for the ill-treatment itself.

It is worth recalling in this context that the purpose of the rules on burden of proof is to ensure that a decision is reached in every case. In factually straightforward cases, the rules on the burden of proof will not feature so prominently, as they will in cases where the facts are unclear. ${ }^{106}$ Caroline Foster has made a strong case for the articulation of the rules on the burden of proof by international courts and tribunals in accordance with the principle of certainty, which primarily means consistency in the application. ${ }^{107}$ In terms of Convention law, this would mean invariably applying the principle of affirmanti incumbit probatio, namely that the burden of proof in relation to an allegation lies on the party which makes it. ${ }^{108}$

However, Foster emphasises that there should remain scope for flexibility in the application of the rules on the burden of proof in order to deal with concerns about potential unfairness in particular cases, such as where the parties do not share equal access to important evidence. ${ }^{109}$ Indeed, fairness is one of the central considerations related to the articulation of the burden of proof. Fairness in this context means, inter alia, achieving a rough equality between the parties and minimising the risk of an erroneous outcome. A proper distribution of the burden of proof is capable of allocating such a risk between the parties. ${ }^{110}$

In order to achieve this fairness, it is often suggested in legal theory that the burden of proof should not necessarily be on the party that makes an allegation but should rather be allocated to the litigant with the best access to relevant information. ${ }^{111}$ This can be expressed through the maxim according to which 'he should have the burden on whom it would sit lightest'. However, in the practice of international litigation this principle does not operate consistently and it may happen that

\footnotetext{
105 Operative facts are those forming the legal basis of the central question of a dispute on which the merits of its determination depend. These are facts which are constitutive and dispositive in a sense of being capable to change legal relations. They should be differentiated from evidential facts, which are relevant for the decisionmaking process in reaching a conclusion on the legal questions involved in the matter because they allow for inferring another (operative) fact. All other facts are, from the perspective of the subject matter of a dispute, legally irrelevant (Hohfeld, Fundamental Legal Conceptions as Applied in Judicial Reasoning and Other Legal Essays (1919) at 32-35).

${ }^{106}$ Foster, supra $\mathrm{n} 86$ at 29.

107 Ibid. 31.

108 Merabishvili v Georgia [GC] para 311.

${ }^{109}$ Foster, supra n 86 at 39.

110 Ibid. 35-36.

${ }^{111}$ Shelton, supra $\mathrm{n} 85$ at 384.
} 
the party with a hampered access to evidence will still bear the burden of proof. ${ }^{112}$ Thus, here, fairness - which would normally be achieved by allocating the burden of proof to the party on whom it would sit lightest - is traded for certainty and consistency in the application of the general burden of proof in accordance with the principle affirmanti incumbit probatio.

In order to alleviate the unfairness associated with such a state of affairs, different techniques are used in international litigation. In particular, an adverse inference may be drawn where a party does not cooperate with international courts and tribunals in bringing forward evidence that it is capable of producing. Moreover, the prima facie approach is used, which means that it is accepted that certain evidence, although unexplained or uncontradicted, is still sufficient to maintain the proposition affirmed, if such proposition is not rebutted. Similarly, the application of presumptions is another legitimate judicial method for the evaluation of evidence, which includes the possibility for an international court or tribunal to draw inferences from a particular state of affairs. ${ }^{113}$

In view of the above, in international litigation over the allegations of ill-treatment by state agents, the shifting of the burden of proof to the authorities to provide an explanation for the prima facie credible allegations of state responsibility for ill-treatment simply reflects the reality of humanrights litigation. An applicant will never be on an equal footing with the government to provide conclusive evidence related to the circumstances in which the state agents used force against him or her. Applicants will lack both the resources and the power that the state has to investigate the event and to collect evidence.

The same is true for the Court. As its determination of the cases depends on the parties' capacity and willingness to produce evidence, it must draw adverse inferences when the government, which is best equipped to produce such evidence, fails to do so. ${ }^{114}$ The Court has stressed that it is sensitive to any potential evidentiary difficulties encountered by a party and that the strict application of the principle affirmanti incumbit probatio is not possible in instances where applicants have specific evidentiary difficulties in collecting and producing evidence. ${ }^{115}$

In the context of the criminal-law protection of human rights, the instrumental value of the procedural obligation under the Convention reflects the state's duty to discharge its burden of proof by providing an explanation for the credible allegations of ill-treatment. In other words, the state is obliged to conduct an official effective investigation and, if appropriate, prosecution in order, inter alia, to elucidate the circumstances of the events. Failure by the state to do so, should lead to the drawing of negative inferences concerning the scope of the state's responsibility.

On the other hand, reliance on an applicant to provide evidence that would satisfy the standard of proof 'beyond reasonable doubt', out of the context of the state-led criminal investigation and prosecution, would often place him or her in an impossible situation. In fact, it is difficult to see how in practical terms an applicant could produce such evidence without instituting some sort of private investigation aimed at collecting evidence sufficient to convince the Court that the ill-treatment has

\footnotetext{
112 Foster, supra $\mathrm{n} 86$ at 35-36.

113 Ibid. 50-59.

${ }^{114}$ These arguments are a development of Shelton's discussion on the shifting of the burden of proof in the proceedings before the Inter-American Court of Human Rights (Shelton, supra $\mathrm{n} 85$ at 384).

115 Merabishvili v Georgia [GC] paras 311 and 315.
} 
occurred. This would, of course, be excessive as it would not only run counter to the above-discussed principle of fairness in evidence law but would also often be inoperative in practice.

Moreover, placing such a requirement on the applicant would invariably require the Court to take on the role of a first-instance tribunal of fact. This, however, as discussed above, the Court should do only when it is rendered unavoidable by the circumstances of a particular case. At the same time, as the state will always have the procedural duty to investigate when there is an arguable claim of illtreatment by state agents, the circumstances in which it would be unavoidable for the Court to assume that role should normally never arise. Accordingly, since the Court should be capable of relying on the findings of the domestic proceedings, the compliance with the procedural duty must be decisive for the assessment of compliance with the substantive requirements. From this perspective, it is axiomatic that a relevant procedural breach marring the authorities' capacity to provide an explanation for the arguable claim of ill-treatment should lead to an adverse finding on the substantive aspect of the protection as well. ${ }^{116}$

In this connection, the principle in the Court's case-law that 'the events in issue [should] lie wholly, or in large part, within the exclusive knowledge of the authorities' for the burden of proof to be shifted to the authorities', should be interpreted in line with the nature and purpose of the procedural obligation and its above-discussed interplay with the Court's rules of evidence. These considerations direct to a conclusion that the shifting of the burden of proof as conceived in the Bouyid judgment, in relation to the exclusive knowledge of the authorities, should cover their (exclusive) capacity to elucidate the circumstances of the events and to provide an explanation for the credible allegations of ill-treatment under Article 3.

This also follows from the Court's dictum in Merabishvili where it stressed that negative inferences may be drawn from the state's failure to account for credible allegations of a breach of a Convention right in instances in which the state alone has access to information capable of corroborating or refuting the applicant's allegations. ${ }^{117}$ The Court thereby referred to the cases of persons in custody of the authorities only by way of example. There is therefore nothing in the Court's general rules on the shifting of the burden of proof to draw inferences from a failure of the state to provide an explanation for the applicant's allegations of ill-treatment that would limit these principles only to the context of custody.

Moreover, the reference to the 'control of the police or a similar authority' should be interpreted as the 'exercise of physical power and control over the person in question', ${ }^{118}$ which essentially happens every time force is used against an individual. In any event, from the perspective of the noted difficulties in producing evidence by applicants - which is a decisive matter in the interpretation of the principle of fairness in this context - there is little if any difference between various situations in which ill-treatment may occur. Thus, in all such instances in which force is used

\footnotetext{
${ }^{116}$ It should be noted in this context that providing an explanation for the allegations of ill-treatment does not necessarily imply conviction of any person (see above at Section 4.B). Whether a conviction is warranted in the circumstances of a particular case is another matter which has no direct bearing on the discussion in question. ${ }^{117}$ Merabishvili v Georgia [GC] para 313.

${ }^{118}$ This is borrowed from the Court's principles on the exercise of the state extraterritorial jurisdiction, which is a concept linked to the state responsibility for acts and omissions allegedly breaching the Convention (Al-Skeini and Others $v$ the United Kingdom Application No 55721/07, Merits and Just Satisfaction, 7 July 2011 para 136). From the perspective of harmony in the interpretation of the Convention, there is no reason not to apply this standard for asserting the state's responsibility for the acts and omissions of its agents that happen internally.
} 
against an individual, causing injuries that prima facie suggest ill-treatment, the burden of proof should be shifted to the government to provide explanations by conducting an official effective investigation into the event.

It is, of course, possible that the shifting of the burden of proof to the government and drawing of adverse inferences from the domestic authorities' procedural failures would lead to an erroneous conclusion as to the state's responsibility for the ill-treatment itself. However, it is equally possible that not shifting the burden of proof and allowing the government to benefit from its own procedural failures would lead to an erroneous conclusion as to the state's non-responsibility for illtreatment that has actually taken place. It should be accepted that there would always be a risk of an erroneous outcome. The question is only how to minimise it and whether gravity of a possible error in favour of one party outweighs the gravity of a possible error in favour of the other. ${ }^{119}$

From the perspective of the minimisation of error, an important aspect is the required likelihood that complaints are well-founded expressed through the requirement that applicants must provide a consistent and as detailed as possible account of the events and to provide all evidence at their disposal. This falls under the threshold criterion of 'arguable claim' or 'credible assertion', which, if not met, leads to the inadmissibility of the application. ${ }^{120}$ Moreover, as in any event the state has a separate and autonomous duty under the Convention to conduct an official effective investigation into an arguable claim of ill-treatment, by applying the international law presumption of compliance and thus assuming that the state will conduct such an investigation, minimises (at least in theory) the risk that an erroneous conclusion on the question of the state's responsibility for ill-treatment will be reached. However, if in the particular circumstances of the case the state fails to discharge this procedural duty properly, then inevitably the negative inferences must be drawn.

As to the weight attached to the possible error in the outcome, it should of course be accepted that in the abstract the state and individuals share the same ideas of the purpose of international justice and equally draw benefits from a proper adjudication of disputes over human rights-related matters. ${ }^{121}$ Thus, without doubt, errors in international adjudication could be detrimental to individuals and states in a similar measure.

However, in the particular context of ill-treatment by state agents, this general assertion should be viewed in the light of the fact that a particularly important aspect of human rights protection is at stake. Indeed, possible errors in identifying and ensuring accountability for ill-treatment falling under Article 3 of the Convention could make the general legal prohibition of torture and inhuman and degrading treatment, despite its fundamental importance, ineffective in practice ${ }^{122}$ and could thereby undermine the very essence of the rule of law and trust in the effectiveness of international human rights protection.

On the other hand, the state, which has the operational capacity and legal duty to conduct an official effective investigation into the credible allegations of ill-treatment, has the possibility of managing and minimising the error and, should it fail to do so, simply has to live with the

\footnotetext{
${ }^{119}$ These arguments are inspired by the law-economics perspective in evidence law which looks into the issue of the allocation of the burden of proof from the perspective of the relative costs of proof, the costs of error and the estimated likelihood that complaints will be well-founded (Foster, supra $\mathrm{n} 86$ at 38).

120 See above $\mathrm{n} 20$.

121 Thienel, supra $\mathrm{n} 83$ at 585.

122 Gäfgen v Germany [GC] Application No 22978/05, Merits and Just Satisfaction, 1 June 2000 para 119.
} 
consequences. Moreover, as discussed earlier, it would be paradoxical to accept that by not investigating the credible allegations of ill-treatment, the state could benefit from its own mistakes by avoiding the finding of a more serious breach of the substantive aspect of the right.

In sum, it follows from the above discussion that in cases concerning the credible allegations of police ill-treatment, the shifting of the burden of proof to the authorities is warranted by the very conceptual requirements of the substantive-procedural relationship. In this context, the shifting of the burden of proof constitutes a legitimate tool in achieving fairness in the proceedings and arriving at a sensible resolution of the case. In practical reasoning, the shifting of the burden of proof means attaching decisive importance to the state's procedural obligation, the discharge of which then becomes instructive for the assessment of the state's compliance with the substantive aspect of the protection. Consequently, in each case primacy should be given to the procedural aspect, both in terms of the order of examination and inferences to be drawn on the question of observance of human rights by states.

\section{CONCLUSION}

There are still many aspects of the concept of coercive human rights law that are subject to a gradual development and affirmation in legal theory and practice. The current article has observed certain theoretical and conceptual inconsistencies and gaps arising in the context of the interaction between the substantive and procedural aspects of criminal-law protection of human rights in the practical reasoning of human rights law. The different approaches to the question of the substantive or procedural primacy in the Court's case-law provide sufficient evidence for this assertion.

This article has sought to argue that there is a need for the court reviewing criminal justice processes from the Convention perspective in each case to examine both aspects - substantive and procedural - of the same right and to give precedence to the procedural aspect, both in terms of the order of examination and inferences to be drawn on the question of observance of human rights by states.

By devising this methodological structure, this article represents an attempt of legal theory to recognise, analyse and place in the right context the different considerations, including misgivings, about the substantive-procedural relationship in practical legal reasoning. It is only hoped that it will be capable of adding to the debate on the demanding theoretical and practical considerations underlying the concept of coercive human rights law to the ultimate benefit of an effective protection of victims of human rights offences. 